\title{
PORODIČNI BIZNIS KAO RAZVOJNA ŠANSA PRIVREDE SRBIJE
}

\section{FAMILY BUSINESS AS A DEVELOPMENT CHANCE OF THE SERBIAN ECONOMY}

\section{Milosav Miličković}

Poslovni i pravni fakultet, Univerzitet „Union Nikola Tesla”, Beograd, Srbija

Alshibani Warda Muftah Shafee

Poslovni i pravni fakultet, Univerzitet „Union Nikola Tesla”, Beograd, Srbija

\section{Miroslav Jevremović}

Poslovni i pravni fakultet, Univerzitet „Union Nikola Tesla”, Beograd, Srbija

CMESTE

JEL kategorija rada: D13, L26

\begin{abstract}
Apstrakt
Porodični biznis sadrži određene specifičnosti od organizacione forme, finansiranja, nasleđivanja, rizika, osiguranja i drugog. Porodično poslovanje je jako važno zato što predstavlja značajan deo svake nacionalne ekonomije $i$ direktno utiče na blagostanje $i$ stabilnost čitave zemlje, međutim još uvek ne postoji dovoljno razvijena svest o njenom uticaju pa samim tim ovakvo poslovanje nije dovoljno istraženo. Da porodično poslovanje nije dovoljno istražno dokazuje to što $i$ u tržišnim privredama ne postoji dovoljno literature o ovakvom načinu obavljanja poslovanja, pa samim tim zainteresovana lica nemaju uvid u mogućnosti koje ono pruža, kao ni probleme i rizik koji se moraju uzeti u obzir pre otpočinjanja porodičnog poslovanja. Predmet ovog rada je upravo nastanak, razvoj, ideje, prednosti $i$ mane uopšteno porodičnog biznisa. Cilj je da se prikaže ova ideja koja može da omogući kompletnu finansijsku i organizacionu analizu poslovnog poduhvata tj.koja su inicijalna sredstva i koje radove je potrebno preduzeti i izvršiti da bi se još više razvio porodični biznis u Srbiji, a i šire.
\end{abstract}

Ključne reči: preduzetništvo, inovacije, rizik, porodica, biznis

\begin{abstract}
Adresa autora zaduženog za korespodenciju Milosav Miličković

莑”milickovicm@gmail.com
\end{abstract}

The family business contains certain specifics from the organizational form, financing, inheritance, risk, insurance, and others. Family business is very important because it represents a significant part of every national economy and directly affects the well-being and stability of the whole country, but there is still not enough developed awareness of its impact, so this kind of business is not sufficiently researched.

That family business is not sufficiently researched is proved by the fact that in market economies there is not enough literature on this way of doing business, so stakeholders do not have insight into 
the opportunities it provides, as well as problems and risks that must be considered before starting a family business. The subject of this paper is precisely the origin, development, ideas, advantages, and disadvantages of the family business in general. The goal is to present this idea, which can enable a complete financial and organizational analysis of the business venture, ie what are the initial funds and what works need to be undertaken and performed to further develop the family business in Serbia and beyond.

Keywords: entrepreneurship, innovation, risk, family, business

\section{POJAM, DEFINICIJA I KARAKTERISTIKE PORODIČNOG BIZNISA}

Porodičan biznis predstavlja pojam kojim se zajednički opisuje uključenost porodice u obavljanje određenih društvenih delatnosti s ciljem ostvarenja profita, bez obzira na institucionalni aspekt (preduzeće, zanat, zadruga) putem kojeg se delatnost vodi, obavlja i kontroliše.

Porodična preduzeća su se pojavila pre 4.000 godina. Porodičan biznis predstavlja najpopularniju i najčešće zastupljenu formu vlasničkog organizovanja i upravljanja poslovanjem u svetu. Pre pojave akcionarskih društava, porodični biznis je predstavljao jedini oblik organizacije poslovanja, a danas predstavlja dominantan oblik poslovanja i okosnicu razvoja svetske privrede.

IFC Priručnik za upravljanje porodičnim firmama daje sledeću definiciju: termin porodična firma se odnosi na preduzeće u kojem je većina glasova u rukama porodice pod čijom kontrolom je firma, uključujući osnivača (osnivače) koji nameravaju da prenesu firmu na svoje potomke. Pojmovi „porodično poslovanje“, „porodična firma“, „porodično preduzeće“, „firma u porodičnom vlasništvu“, „preduzeće u porodičnom vlasništvu“ $i$ „preduzeće koje kontroliše porodica“ koriste se kao ekvivalenti i uvek se odnose na porodične firme. (Abouzaid, 2008, str. 11)

Po definiciji porodičnog biznisa EU (EC, 2009):

- Većinu prava odlučivanja ima osnivač ili osoba koja je kupila preduzeće i najbliži srodnici

- Uključenost u upravljanje preduzećem najmanje jedna osoba

- Preduzeće na tržištu deonica - osnivač / vlasnik dela preduzeća sa srodnicima i naslednicima poseduju najmanje $25 \%$ prava odlučivanja.
Porodično preduzeće obuhvata sledeće elemenate (Tišma, 2007):

- rod, krvno srodstvo, odnosno rodbina,

- vlasništvo, deo kapitala prduzeća,

- kontrola, kao mogućnost da utiču na donošenje odluka - koja proizilazi iz skupa upravljačkih i vlasničkih prava i obaveza.

Za definisanje porodičnog biznisa koriste se sledeći kriterijumi u tri različite kategorije:

- Najšira definicija porodičnog biznisa: zahteva da porodica ima određeni stepen efektivne kontrole nad razvojem strategija i da makar mali deo biznisa ostaje u vlasništvu porodice.

- Srednja definicija: uključuje sve kriterijume najšire definicije, ali zahteva da osnivač ili potomak rukovodi preduzećem.

- Najuža definicija porodičnog biznisa: zahteva da je nekoliko generacija unazad uključeno u biznis direktno, zatim porodično angažovanje u svakodnevno poslovanje i da više od jednog člana ima značajne menadžerske odgovornosti. (Borota, 2007, str. 14)

Zajednički imenitelj svih porodičnih biznisa je puno rada, mnogo rezultata i mnogo novih ideja od kojih se mnoge ostvare, a veliki broj čeka na realizaciju neko bolje vreme i bolje uslove rada.

Karakteristike porodičnih preduzeća (Tišma, 2007, str. 136):

- Centar preduzeća - Porodica (formalno i neformalno / direktno ili idirektno) utiče na poslovanje firme.

- Neophodno upravljanje - U sferi preduzeća i porodice.

- Glavni cilj - Ekonomski i neekonomski (održivi I dugoročni izvor prihoda za porodicu stabilnost i zadovoljstvo porodice)

- Preovlađujući način razmišljanja - Prenos na sledeću (e) generaciju (e), održivost životnog vekapreduzeća.

- Strategija konkurentnosti - Kvalitet, reputacija, dugoročni odnosi. 
- Imovina - Finansijska, drištvena, kulturna.

- Klima u kompaniji - Familijarnost, poverenje, kohezija, uključenost, posvećenost, entuzijazam, neformalnost.

- Poslovna orjentacija - Zadovoljstvo internih i eksternih interesnih grupa (uglavnom porodice, klijenata, zaposlenih, lokalne zajednice).

- Stil menadžmenta - Vođen porodičnim vrednostima, emotivan, usklađen sa ciljem.

- Alokacija profita - Reinvestiranje.

Činjenica da je vlasnik preduzeća, u stvari porodica, manifestuje se gotovo u svim segmentima poslovanja. Za porodična preduzeća karakteristično je dugoročno planiranje ili barem vizija osnivača da će njegov rad preživeti dugi niz godina. $\mathrm{Na}$ taj način, uspešna porodična preduzeća pružaju posebne mogućnosti za kombinovanje karijere i ličnog života članovima porodice, ženama, kao i zaposlenima koji nisu članovi porodice, ali i lokalnoj sredini ( zajednici ) u kojoj žive i rade. (Đurić, 2015, str. 320)

„Istovremeno, članovi porodice koji dele preduzetničku želju da prošire postojeće poslovanje, za tako nešto imaju čvrstu osnovu." "Naime, u porodičnim preduzećima žene imaju mogućnost da fleksibilnije rasporede svoje radno vreme, što im olakšava obavljanje tradicionalne uloge $u$ porodici i kombinovanje materinstva sa profesionalnom karijerom. Takođe, zaposleni koji ne pripadaju porodici su za svoj rad u porodičnom preduzeću bolje nagrađeni; fluktuacija zaposlenih je manja, pa otuda zapošljavanje u porodičnom preduzeću znači veću odgovornost za dugoročnu socijalnu sigurnost." (Tišma, 2007, str. 136)

Partneri u porodičnom biznisu mogu da budu: bračni partneri, rođački, prijateljski ili partneri po interesu. Međutim, ima situacije, kada se javlja, samostalni-preduzetnik osnivač koji je imao dovoljno hrabrosti i istarjnosti da sam pokrene vlastiti biznis. Svesno ili nesvesno, tog trenutka preduzetnik osnivač je pokrenuo porodičnu kompaniju koja se ustoličila u svojoj prvoj životnoj fazi. Formalno ona će postati porodična tek kada on ili njegova deca zajednički odluče ili požele da se novo pokoljenje priključi kompaniji. I tada, kada se neminovno pojavi nova menadžerska uloga $u$ liku gazdinog sina - kompanija polako izlazi iz svoje prve faze razvoja porodičnih kompanija. A u narednu fazu ulazi onoga trenutka kada osnivači počnu da razmišljaju o povlačenju ili kada život bude odlučio da moraju da se povuku. Sasvim je prirodno da će mnoge od njih upravo naslediti druga generacija iz porodice. (Vord, 2006)

Statistike kažu da sve svetske ekonomije porodični posao smatraju saveznikom i veoma važnim za privredni i socijalni razvoj svake države. To će polako i sigurno postati uobičajeno i kod nas, s obzirom na broj nezaposlenih, posebno onih koji su prevalili petu deceniju. Porodična preduzeća zapošljavaju više od $70 \%$ radnika i imaju veliko učešće u ekonomskim outputima. Pomažu rastu ekonomije u celini. Imaju postojanu strukturu kapitala koja omogućava održivu strukturu finansiranja, strategiju i performanse. Imaju tendenciju rasta ka radno - intenzivnim, a manje ka kapitalno - intenzivnim delatnostima. Postižu inovacije sa relativno nižim troškovima, crpe interne resurse kapitala. (Vord, 2006)

Osnovni tipovi porodičnog biznisa su (Tišma, 2007, str. 136):

- Aktivna porodična preduzeća - lični nadzor poslovanja od strane članova porodice. Vlasništvo preduzeća je u rukama članova porodice, koji su uključeni u proces poslovanja i koji su zaposleni u preduzeću. Mogu zapošljavati i radnike koji nisu članovi porodice.

- Porodična preduzeća sa odsutnim vlasnikom preduzeća - vode in ne-članovi porodice u ime i za račun porodice.

- Latentna (pritajena) porodična preduzeća samo jedan član porodice, najčešće vlasnik ili zakonski naslednik uključene je u procese poslovanja ili vođenja preduzeća.

Većina porodičnih preduzeća su mala preduzeća. Međutim, postoji dosta primera porodičnih firmi, koji su od malog biznisa postale velike korporacije kao što su Fiat, Ford, Mercedes, Samsung, LG itd. Ali i kada porodični biznis preraste u veliku korporaciju, mišljenje porodice se i dalje uvažava, a porodica osnivača, po pravilu nastavlja da učestvuje u donošenju odluka i upravljanju korporacijom. Svi oni koji su, u zadnjih 15-20 godina, sami ili sa partnerima pokretali svoja preduzeća su na neki način u porodičnom biznisu. (Đurić, 2015, str. 320) 


\section{POSVEĆENOST POSLU JEDINSTVENA ATMOSFERA, KAO KLJUČNE KARAKTERISTIKE PORODIČNOG BIZNISA}

Preduzetnički biznis svoj razvoj uglavnom počinje kao porodični biznis u kome se isključivo angažuju članovi porodice. Ključna karkteristika, koja porodični biznis razlikuje od ostalih, jeste jedinstvena atmosfera koja kreira osećaj pripadanja i pri tome bitno pojačava važnost zajedničkih ciljeva kod svih zaposlenih. Dok je posvećenost poslu jedan od ključnih elemenata porodičnog biznisa.

Preduzetnici, kao idejni kreatori, svom poslu pristupaju sa puno energije, strastveno i to u svim fazama razvoja proizvoda i posla. Posao predstavlja život što se neminovno prenosi i na ostale članove porodice. Ovakva atmosfera kreira i veoma pozitivan odnos zaposlenih koji nisu članovi porodice, utičući na njih da porodičnu firmu sve više prihvataju kao svoju, pri čemu motivisane radnike nije teško prepoznati.

Jedinstvena atmosfera i posvećenost poslu u porodičnom biznisu stvara motivisane radnike koji: spontano, slobodno izražavaju svoje idejei sugestije, pozitivno se odnose prema novim zadacima i povećanim zahtevima, rade da bi postigli rezultate, precizni su i snalažljivi u svim segmentima obavljanja posla, vode računa o organizovanosti i urednosti radnog mesta, vode računa o ličnom nastupu i izgledu.

Porodični biznis vrlo često ima specifičan knowhow koji se ogleda u posebnim tehnikama i veštinama obavljanja posla koje ne poseduje konkurencija. Velika posvećenost poslu članova porodice omogućava da se bez posebnih debata o prekovremenom radu posao završi na vreme. Posvećenost u porodičnom biznisu, takođe, pomaže u brzini donošenja odluka i reagovanja na nove poslovne mogućnosti pri čemu se zaobilaze hijerarhijske strukture.

Stabilna poslovna kultura u porodičnom biznisu, iako veoma važna, može da bude dvosekli mač, jer kreira vrlo opasnu zatvorenu atmosferu u kojoj stav: mi ovo radimo na ovaj način od početka to radimo tako, može da stvori kod zaposlenih osećaj da niko ne razmišlja o promenama koje mogu da doprinesu većoj efikasnosti. (Tišma, 2007, str. 136)

Da se ne bi upalo u zamku samoponavljanja i neinventivnosti porodično preduzeće treba da stalno traga i uključuje u svoj rad nove saradnike, koji sa sobom donose nove ideje. Saradnici koji su van porodice mogu biti zaraženi optimizmom, a mogu i samo na korektan način obavljati svoj deo posla. Šta će se od toga desiti umnogome zavisi od članova porodice, da li će oni saradnika sa strane prihvatiti kao sebi ravnog ili će postojati određena hijerarhija. Predlog je sledeći:

- Priličan stepen autonomije treba da postoji u kreativnom delu to jest u osmišljavanju novih motiva ili novog proizvoda.

- Hijerarhija u odlučivanju naravno mora postojati, ali se mišljenja saradnika i njihovi predlozi moraju razmatrati ravnopravno sa predlozima članova porodice.

\section{MERE PORODIČNOG BIZNISA}

Da bi porodični biznis imao veći uticaj na društveno ekonomski razvoj zemlje potrebno je preduzeti sledeće:

- Da vladina politika značajnije prepoznaje društveni i ekonomski značaj porodičnog biznisa.

- Da vlada da definiciju porodičnog biznisa.

- Da se sprovedu statistička istraživanja vezana za porodični biznis.

- Kreiranje regulatornog okvira za transfer vlasništva na najeftiniji i najjednostavniji način.

- Poboljšati edukaciju.

- Razvijati nove mehanizme finansiranja porodičnog biznisa.

- Odrediti institucije koje će prikupljati podatke i slušati problem koji dolaze iz porodičnog biznisa.

- Uključiti predstavnike porodičnog biznisa u privatno javni dijalog.

- Osnovati ekspertsku grupu za predlaganje politika i instrumenata prema porodičnom biznisu.

- Država treba da analizira i primere dobre prakse politika prema porodičnom biznisu u Holandiji, Sloveniji, Španiji i Belgiji. (Đurić, 2007, str. 54) 
4 IZAZOVI I OGRANIČAVAJUĆI FAKTORI ZA PORODIČNI BIZNIS U SRBIJI

Pokrenuti i voditi porodični biznis na početku 21. veka u Srbiji je znatno teže nego u razvijenim zemljama i zemljama EU.

Izazovi uključuju:

- Ograničene resurse (ljudski rad, kapital, tržišne mogućnosti).

- Specifične forme organizacije koje često imaju sopstveni pristup (preduzetničkom) menadžmentu.

- Potrebu za odgovarajućim fokusom na dugoročnu politiku razvoja.

- Ranjivost u odnosu na različite stejkholdere vladu.

- Interesne grupe.

- Poteškoće u obezbeđivanju finansijske podrške.

- Ekonomske poteškoće (turbulenciju) u okruženju.

- Nedostatak odgovarajuće institucionalne podrške.

- Poreski sistem (na republičkom i lokalnom nivou)

- Regrutaciju odgovarajuće (kvalifikovane) radne snage.

Porodični biznis sve više dobija na značaju, imajući u vidu aktuelno stanje u privredi Srbije nezaposlenost i nedostatak finansijskih sredstava. Rešavanje tih gorućih problema postaje imperativ ne samo za nosioce vlasti, već se i od svih građana Srbije očekuje da preuzmu proaktivnu ulogu u iznalaženju načina za pokretanje dinamičnijeg privrednog rasta. Iskustva razvijenih zemalja, posebno Evropske unije gde porodična preduzeća imaju odlučujuću ulogu u rešavanju nezaposlenosti i pokretanju dinamičnog rasta, mogla bi da nam posluže kao primer. U privredi EU posluje više od 17 miliona porodičnih preduzeća koja zajedno generišu preko 65 odsto ukupne zaposlenosti i bruto domaćeg proizvoda. U razvijenim zemljama najveća koncentracija porodičnih preduzeća je u tradicionalnim sektorima privrede poput uslužnog, tekstilne industrije, male proizvodnje i građevinarstva. Učešće u sektorima visoke tehnologije je nisko, jer u većini slučajeva nisu skloni preuzimanju rizika i ne raspolažu kapitalom za neophodne investicije.
Koncept porodičnih preduzeća, upravo omogućava dugoročniju stabilnost u poslovanju. $U$ pitanju je fenomen koji u svojoj osnovi ima tri elementa - porodica, biznis, vlasništvo.

Porodično preduzeće odlikuje dugoročna stabilnost, uspešnost u poslovanju, i veći stepen rezistentnosti u uslovima krize. Porodična preduzeća na kratak rok nisu vođena isključivo profitom, već su im na prvom mestu bezbednost i stabilan rast .Brojni su uspešni primeri porodičnog biznisa u Srbiji kao što su „Ekstrim Intimo“, „Ivančić i sinovi“, „Nektar“...

Prepreke za razvoj porodičnog biznisa u Srbiji su brojne:

- Specifičnost mentaliteta.

- Nedovoljno preduzetničkog duha.

- Otežan pristup povoljnim izvorima finansiranja.

- Malo znanja iz oblasti budžetiranja, izrade biznis planova i planova proizvodnje.

- Nedovoljna zastupljenost koncepta porodičnih preduzeća na Univerzitetima kao i u političkim programima stranaka.

- Mali broj eksperata koji bi mogli da pomognu razvoj porodičnog biznisa.

Osnovni koraci u podsticanju porodčnog biznisa trebalo da budu usmereni na:

- Izgradnju institucijalnog okvira,

- Donošenje zakonske regulative u vezi sa porodičnim preduzećima,

- Uvođenje statističkog praćenja i obrade podataka o porodičnim kompanijama,

- Promena percepcije u javnosti o tim firmama. Trenutno ove firme se više percipiraju kao sociološki fenomeni a ne kao pravne kategorije.

Nekoliko saveta da se započne porodični biznis:

- Negujte poslovnu i pragmatičnu svest ako želite da imate svoju firmu, nužno je i da imate određeno iskustvo na osnovu kojeg poznajete odgovarajuće veštine koje su potrebne za vašu profesiju.

- Potrebno je da razvijete biznis plan i da imate odgovarajuće kontakte na tržištu na koje možete da se oslonite;

- Greška je ući u biznis bez dobrog poslovnog plana neophodna je projekcija polsovanja barem u periodu od tri godine. 
- Iskustvo je pokazalo da je obično treća godina najkritičnija za privatne firme jer se mnoge tada i gase;

- Potražite savet stručnjaka kako bi ste odredili koliko će vaš posao biti unosan, kada će početi da donosi zaradu, koliko dugo smete da budete na nuli tek kada prikupite dovoljno znanja možete da uletite u posao.

- Potrebno je malo mašte, hrabrenja sebe, ali i velika doza realnosti kako biste mogli da predvidite rizike i način na koji će te prevazići probleme. Potrebno je mnogo rada i truda sve vreme morate da gradite preduslove kako biste mogli da iskoristite povoljan momenat za razvoj posla.

- Kao vođa firme, potrebno je da se razvijate multidisciplinarno trebalo bi da ovladate veštinama za razvoj posla, da prepoznate gde je mesto marketingu, kako da razvijete dobre odnose sa klijentima, da razumete tržište na kome nastupate i svoju proizvodnju.

- Sa razvojem firme, svaki dobar preduzetnik mora da prepozna i trenutak kada je potrebno da razdvoji funkciju vlasnika i funkciju upravljanja ovde preduzetnici teže da ceo posao drže u svojim rukama. Ali kada obim poslovanja pređe određene granice, potrebno je da se oformi tim koji će upravljati firmom. Inače se pravi usko grlo koje šteti porodičnom preduzeću.

- Porodica i privatni biznis mogu da se uklope, ali ne postoji univerzalni recept kao preduzetnici raspolažete vremenom kako vama odgovara, što znatno olakšava uspostavljanje ravnoteže između porodičnog $i$ poslovnog života. (Jovanović, 2001, str. 63)

\section{ZAKLJUČAK}

Porodični biznis je jedna celina koju čine tri elementa: porodica-firma-imovina. Kada se između porodice, firme i imovine postigne ravnoteža, može se garantovati budućnost porodičnom kapitalu. Preduzetničko poznavanje porodičnog biznisa, odnosno znati kako uspešno voditi svoju porodičnu firmu: ključ je uspeha $i$ prosperiteta preduzetnika, njegove imovine i porodice. Neophodno je učenje i obuka, posebno zato što oni koji preuzmu postojeći porodični biznis moraju da se suoče sa ograničenjima postojećih investicija i menadžerske prakse, aspekata koje je neophodno razumeti u potpunosti.

I u otežanim uslovima porodični biznis mora biti pokretač izlaska iz krize. Porodične kompanije pokazale su se vitalnim i uspešnim delom privrede u svim ekonomijama sveta.

lako teorija tvrdi da je kod privatnog biznisa lakše ograničiti radno vreme na željeni broj sati, iskustvo je pokazalo da ta teorija baš i nije tačna, samim tim što je posvećenost poslu kod ličnog porodičnog biznisa veća. Tako se vrlo često dolazi u situaciju da se većina drugih obaveza podredi biznisu, pa i porodična okupljanja ne mogu da prođu makar bez priče o planovima o budućnosti kako porodice, tako i porodičnog biznisa. Vrlo često se zbog obima posla baš članovi porodice žrtvuju kao radnici koji bi radili duže zbog potreba posla. Takođe sam primetila da podela rada $i$ dužnosti nije jasno definisana, odnosno podela postoji, ali su odstupanja mnoga, jer svako želi da pomogne i svi sve rade. To može s druge strane da se posmatra i kao velika prednost u takvom porodičnom timskom radu.

\section{CITIRANA DELA}

Abouzaid, S. (2008). IFC Priručnik za upravljanje porodičnim fimama, (prevod). Washington, DC, SAD: International Finance Corporation.

Borota, A. (2007). Menadžment porodičnog biznisa. Beograd: Beogradska poslovna škola.

Đurić, Z. (2007). Biznis plan malih i srednjih preduzeća. Beograd: Beogradska poslovna škola.

Đurić, Z. (2015). Menadžment prodičnig biznisa. Beograd: BPŠ.

EC. (2009). Family business. Preuzeto sa Internal Market, Industry, Entrepreneurship and SMEs: https://ec.europa.eu/growth/smes/supporting-entrepreneurship/family-business_en

Jovanović, P. (2001). Menadžment-teorija i praksa. Beograd: Grafoslog.

Tišma, B. (2007). Menadžment porodičnog biznisa. Beograd: BPŠ.

Vord, D. (2006). Razvoj porodičnih kompanija. Novi Sad: ASEE d.o.o. 
Received for publication: $\quad 24.09 .2020$.

Revision received: $\quad$ 23.03.2021.

Accepted for publication: $\quad$ 05.04.2021.

Kako citirati ovaj rad? / How to cite this article?

Style - APA Sixth Edition:

Miličković, M., Shafee, A. W., \& Jevremović, M. (2021, 04 15). Porodični biznis kao razvojna šansa privrede Srbije. (Z. Čekerevac, Ur.) FBIM Transactions, 9(1), 81-87. doi:10.12709/fbim.09.09.01.08

Style - Chicago Sixteenth Edition:

Miličković, Milosav, Alshibani Warda Muftah Shafee, i Miroslav Jevremović. 2021. „Porodični biznis kao razvojna šansa privrede Srbije." Urednik Zoran Čekerevac. FBIM Transactions (MESTE) 9 (1): 81-87. doi:10.12709/fbim.09.09.01.08.

Style - GOST Name Sort:

Miličković Milosav, Shafee Alshibani Warda Muftah i Jevremović Miroslav Porodični biznis kao razvojna šansa privrede Srbije [Časopis] // FBIM Transactions / ur. Čekerevac Zoran. - Beograd: MESTE, 1504 2021. - 1 : T. 9. - str. 81-87.

Style - Harvard Anglia:

Miličković, M., Shafee, A. W. M. \& Jevremović, M., 2021. Porodični biznis kao razvojna šansa privrede Srbije. FBIM Transactions, 15 04, 9(1), pp. 81-87.

Style - ISO 690 Numerical Reference:

Porodični biznis kao razvojna šansa privrede Srbije. Miličković, Milosav, Shafee, Alshibani Warda Muftah i Jevremović, Miroslav. [ur.] Zoran Čekerevac. 1, Beograd: MESTE, 1504 2021, FBIM Transactions, T. 9, str. 81-87. 